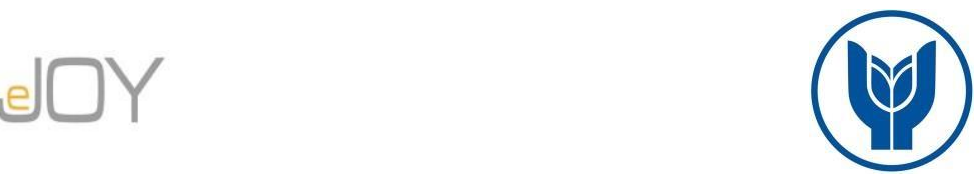

Akbaş, T., T., Arpat, B. / Journal of Yasar University, 2020, 15/57, 1-14

\title{
Ön Lisans Öğrencilerinde Girişimcilik Eğiliminin Demografik Değişkenler ile İliş̧kisi ${ }^{1}$
}

\section{The Relationship Between Entrepreneurial Inclination and Demographic Factors of Students in Associate Degree Program}

\author{
Türkmen Taşer AKBAŞ, Pamukkale Üniversitesi, Türkiye, takbas@pau.edu.tr \\ Orcid No: 0000-0001-5885-2087 \\ Bülent ARPAT, Pamukkale Üniversitesi, Türkiye, barpat@pau.edu.tr \\ Orcid No: 0000-0002-3512-9969
}

\begin{abstract}
Öz: Günümüzde girişimcilik kavramı, özellikle işsizlik ile mücadelenin önemli araçlarından biri haline gelmiş durumdadır. Diğer yandan, ülkelerin kalkınmasinda giriş̧imci bireylerin yetişmesi önemli hale gelmişstir. Bu sebeple girişimcilik kabiliyeti gelişmiş bireylerin eğitim kurumlarında yetişmesini desteklemek gerekmektedir. Bu araştırmanın amacı, ön lisans öğrencilerin girișimcilik eğilimlerinin, cinsiyet, yaș, öğrenim türü ve aile geliri düzeyi ile ilişkisini incelemektir. Veri toplama amacıyla anket yöntemi kullanılmıștır. Araștırmanın verileri; Türkiye'de Ege Bölgesi’nde bir ilçede kurulu meslek yüksekokulunda, birinci ve ikinci ögrretim programına kayıtlı olan 237 g̈ğrenciden, kolayda örnekleme tekniği ile sağlanmıştır. Girişsimcilik eğilimini ölçmek için, Konakay vd. (2017) ile Bilge ve Bal (2012)'in geliștirdiği ölçeklerden faydalanılmıștır. Ön lisans ögrrencilerinin girișimcilik eğilimi, beșli Likert ölçeği ile 23 maddelik ölçek kullanılarak ölçülmüşürr. Araştırmanın yönteminde kesitsel yapı ve iliş̧kisel model tercih edilmiştir. Araştırmanın bulgularına göre, girişimcilik eğiliminin cinsiyet ve öğrenim türü (normal ve ikinci ögrretim) değişkenleri ile ilişskili olmadığg, ancak yaş ve aile gelir düzeyi ile ilişskili olduğu bulgusuna ulaşılmışıtır. Bu konuyla ilgili çalışmaların, ön lisans mezunlarının istihdamına katkı yapması beklenmektedir.
\end{abstract}

Anahtar sözcükler: Girişimcilik Ĕgilimi, Ön Lisans Eğitimi, İstihdam, İssizizlik.

JEL Siniflandirmasi; L26, J23, J24

Abstract: Today, the concept of entrepreneurship has become an important tool in fighting against unemployment. On the other hand, nurturing entrepreneurs has become an essential issue in the development of countries. Therefore, it is necessary to support the training of individuals with entrepreneurship skills in educational institutions. The aim of this study is to investigate the relationship between the entrepreneurial inclination of associate degree students and their gender, age, education type and family income level. Survey method was used for data collection. The data of the study was obtained through convenience sampling method from 237 students studying in daytime and evening education programs of a vocational high school in a district in the Aegean Region in Turkey. In the design of the questionnaire, the scales developed by Konakay et al. (2017) and Bilge and Bal (2012) were benefitted. Entrepreneurial inclination of associate degree students was measured through a five-point Likert scale consisting of 23 items. In the research method, cross-sectional structure and relational model were preferred. According to the findings of the study, it was found that entrepreneurial inclination was not related to gender and education type (daytime and evening education), but was age and related to family income level. Studies on this subject matter are expected to contribute to the employment of associate degree graduates.

Key words: Entrepreneurial Inclination, Associate Degree Program, Employment, Unemployment. JEL Classification; L26, J23, J24

\section{Giriș}

Genç işsizliği, küresel boyutlarda ardı ardına ortaya çıkan ekonomik krizlerin de etkisi ile hem gelişmiş ülkelerde hem de dünya üzerindeki başka ülkelerde baş edilmesi gereken büyük bir sosyo-ekonomik sorundur. Uluslararası Çalışma Örgütü, bu sosyal sorunla mücadele kapsamında, aktif işgücü piyasası politikaları ve uygulamaları önermekte, istihdamı artıran / geliştiren arayışlarda bulunmakta ve bir yandan da girişimciliği bu kapsamda geliştirme arayışlarına katkıda bulunmaktadır. Türkiye için de önemli bir sorun olan genç işsizliği, meslek yüksekokullarında öğrenim gören öğrencileri yakından ilgilendirmektedir. Kısmen bu sebepten olsa gerek, Türkiye'de de girişimcilik eğilimi üzerine yapılan araştırmaların ve analizlerin büyük bir kısmı meslek yüksekokulları -ön lisans- öğrencilerinden sağlanan verilere dayanmaktadır. Meslek yüksekokullarında verilen eğitimin niteliği, staj uygulamaları, girişimcilik derslerinin müfredatta yer alması gibi olgular, girişimcilik eğilimini desteklemekte ve aktif işgücü piyasası politika ve uygulamaları (Acar ve Yabanova, 2017) kapsamında değerlendirilebilmektedir. Konu bu yönüyle Türkiye'de Yüksek Öğretim Kurumu'nun, Türkiye İş Kurumu'nun (İŞKUR), Aile, Çalışma ve Sosyal Hizmetler Bakanlığı'nın, Millî Eğitim Bakanlığı'nın, Kalkınma Bakanlı̆̆ı'nın, Sanayi ve Teknoloji Bakanlığı'nın, Küçük ve Orta Ölçekli İşletmeleri Geliştirme ve Destekleme İdaresi Başkanlığı'nın (KOSGEB) ve Ticaret Bakanlığı'nın faaliyetleri ile yakından ilişkilidir. Girişimcilik, yeni iş imkanları ve zenginlik yaratmanın, bireysel ve toplumsal gelişimin sağlanmasının yanında, iktisadi ve sosyal kalkınmanın, ülke ekonomisinin rekabetçiliğini sürdürebilmesinin ve küreselleşme sürecinde ayakta kalabilmesinin de bir yolu olarak görülmektedir (Keat, Selvarajah ve Meyer 2011, 206).

\footnotetext{
${ }^{1}$ Bu çalışma, 20-22 Haziran 2019 tarihleri arasında Balıkesir'de Bandırma 17 Eylül Üniversitesi'nde gerçekleștirilen "II. Uluslararası Uygulamal Ekonomi ve Sosyal Bilimler Konferanst- ICEESS'19" programında sunduğumuz "Ön Lisans Öğrencilerinde Girişsimcilik Eğiliminin Demografik Değişkenler ile İlişkisi" başlıklı özet bildirinin genişletilmiş versiyonudur.
} 
Türkiye'de, mesleki ve teknik eğitimler ön lisans düzeyinde meslek yüksekokullarında verilmektedir. Meslek yüksekokulu öğrencileri dört yıllık öğretim verilen üniversitelerden farklı olarak işgücü piyasasına mezunlarını iki yıl kadar daha kısa sürede ulaştırmaktadır. Meslek yüksekokulları; mesleğe yönelik uygulamalı eğitim ve öğretim yaparak endüstrinin ve sektörlerin belirlediği ihtiyaçlar doğrultusunda vasıflı ara eleman / insan kaynağı yetiştirmeyi hedefleyen dört yarıyıllık yükseköğretim kurumlarıdır. Meslek yüksekokullarında tekniker ve meslek elemanı olarak yetiştirilecek ön lisans öğrencilerinin, problem çözme ve karar alma becerisi olan, sorumluluk üstlenebilen, meslekleri ile ilgili temel bilgi ve becerilerde yetkinlik sahibi, iletişim becerileri gelişmiş, bilgi-iletişim teknolojilerini iyi kullanabilen, verimlilik ilkesini hayata geçirebilen özelliklere sahip olmaları hedeflenmektedir (Atalay, Bayer ve Çelik 2018, 73). Meslek yüksekokulları yerel kalkınma süreçlerinde de Türkiye'de önemli bir rol oynamaktadır (Yıldız 2010, 87). Kimi meslek yüksekokulları (birçok üniversitenin lisans programlarında olduğu gibi) normal öğretim (gündüz öğretim) yanında ikinci öğretim (gece öğretim) programları ile artan öğrenci eğitim / öğretim talebini karşılamaya çalışmaktadır.

$\mathrm{Bu}$ araştırmanın amacı, ön lisans öğrencilerinin girişimcilik eğilimi ile demografik özellikleri arasındaki ilişkiyi belirlemektir. Araştırmada girişimcilik eğiliminin öğrencinin cinsiyeti, yaşı, öğrenim türü ve ailesinin geliri gibi değişkenler tarafından yordanma durumu analiz edilecek ve değerlendirilecektir. Girişimcilik eğilimini etkileyen demografik özelliklerin bilinmesi, başta girişimcilik eğitim programları olmak üzere, girişimcilik içerikli aktif istihdam politikalarının etkinliğini arttıracak politikaların belirlenmesine ve uygulanmasına olanak sağlayabilir. Bu araştırmada ön lisans öğrencilerin girişimcilik eğilimi, kendi bakış açıları ya da öz değerleme esası üzerinden değerlendirilecektir. Değerlendirme için, alan yazında geliştirilen ölçeklerden faydalanılacaktır. Araştırmanın ikinci bölümünde literatür taraması yoluyla girişimcilik kavramı ve eğilimi incelenecek, üçüncü bölümde araştırma yöntemi hakkında bilgilere yer verilecek, dördüncü bölümde ise bulgular ele alınacak ve son olarak "tartışma ve sonuç” bölümünde değerlendirmeler yapilacaktır.

\section{Girişimci ve Girişimcilik Ĕğilimi}

Girişim kavramı, Türk Dil Kurumu'nun (TDK) Sözlüğ̈̈’nde “bir işe girişme, teşebbüs” biçiminde tanımlanmaktadır. Kavram, Türk Dili’nin içinden geçtiği tarihsel süreçte geçmişte teşebbüs kelimesi ile adlandırılırken günümüzde yaygın kullanımıyla girişim biçiminde adlandırılmaktadır. Girişimcilik ise süreç içeren bir olgu olarak, fırsatı görmek ve tanımlamak, fikir geliştirmek, gerekli kaynakları belirlemek, gerekli kaynakları temin etmek, fikri uygulamaya geçirmek ve yönetmek, risk almak biçimindeki faaliyetler dizisini içerir (İrmiş, Durak ve Özdemir 2010, 16-17; Aksoy, Koçanc1 ve Namal 2019; Vidic vd. 2016).

Kendi işini kurmak ve yönetmek, itibar kazanmayı, toplumda birey için iyi bir statüye sahip olmayı da içerdiğinden kimi bireyler için, kimi durumlarda olumlu bir anlam taşımaktadır (Ulucan 2015). Girişimcilik eğilimi organizasyonel ve konvansiyonel istihdamın alternatifi biçiminde, bireyin kendi kendini istihdam etmeye yönelmesidir (Gül ve Beyşenova 2018, 218). Bu eğilim, bireyin yeni bir girişimde bulunma yönündeki yatkınlığına ve niyetine işaret ederken (BayraktarKaradeniz, 2017, 493) bireyin kendi isteği ile planlı davranışta bulunmasının da öncülü sayılabilir (Taş 2016, 50). Bu doğrultuda girişimcilik niyeti ayrıca, alan yazında Ajzen'in (2012) planlı davranış kuramsal modeline dayalı olarak, girişimcilik eğilimini de içeren görece daha kapsamlı bir model ile "girişimcilik niyeti" biçiminde açıklanabilmektedir (Marques vd. 2012, 662; Doğan ve Yılmaz 2017, 663).

Girişimci; bir gereksinimi teşhis ederek iş fikrine dönüştüren ve gerekli riskleri üstlenerek ticari işletme kuran kişi veya kişilerdir (ILO 2018). Girişimci; bilinenleri en iyi şekilde yapan, hünerleriyle aklını birleştiren, belli bir sermayesi bulunan ya da kendisine ait olmayan sermayeleri kullanan, işgücünü ücret karşılığında satın alarak piyasanın ihtiyacını gidermek amacıyla üretim faaliyetinde bulunan, kâr amacı taşıyan ve riskleri üzerine alabilen, analiz yapabilen, planlayan ve bunları yürürlüğe koyup uygulayan ve sonuçlarını denetleyen kişi olarak tanımlanabilir (Şimşek 2008, 117). Başarılı bir girişimcide bulunması gereken özellikler: 1. Uygun kişisel özellikler, 2. Beceri ve deneyimler ve 3. Kaynaklar biçiminde üç başlıkta toplanabilmektedir. Yine ILO'nun “kadın girişimciler için kllavuz” yayınında (2018), uygun kişisel özellikler tanımlanmaktadır. Bunlar: açık fikirli olmak, yaşama olumlu bakış, olaylara nesnel bakmak, çalışkanlık, kararlılık, cesaretli olmak, rekabeti sevmek, kendini geliştirmeye isteklilik, yaptığı hatalardan ders almasını bilmek, hesaplı risk alabilmek, kolay iletişim kurabilmek, sorunları fırsata dönüştürebilmek, olaylara geniş pencereden bakmak, kolay vazgeçmemek ve liderlik özelliklerine sahip olmak biçimindedir. Girişimci davranışın açıklanmasında bireysel / psikolojik özellikler yaklaşımı dışında sosyal faktörler ve çevresel faktörler yaklaşımları da kullanılmaktadır. Örneğin sosyal faktörlerle girişimci davranışın açıklanmasında geçmişte destekleyici kişisel faaliyetlerden kazanımlar, aile geçmişinden gelen kazanımlar, kariyer aşaması gibi faktörlerden yararlanılmıştır. Çevresel faktörlerin girişimci davranışı açıklaması yaklaşımlarında ise, toplumdaki sosyal dinamikler, destekleyici sosyal ve ekonomik kültür, kariyer süreçleri, piyasa şartları, firsatlar, vergi indirimleri ve teşvikler, zenginliğin elde edilmesi ile ilgili kültürel değerler açıklayıcı faktörler olarak kullanılmıştır (Gürol ve Atsan 2006, 28).

Alan yazındaki araştırmalarda girişimcinin özellikleri genellikle: Başarı ihtiyacı, risk alma, belirsizliğe tolerans, kontrol odağ1, kendine güven, yenilikçi olabilmek / amaçlar seti oluşturma biçiminde açıklanmaktadır (Koh 1996, 14-16; İrmiş, Durak ve Özdemir 2010, 22-26). Alan yazında bu kişilik özelliklerini taşıyan bireylerin girişimci eğilime sahip olduğu varsayımına dayanan birçok araştırma (Koh 1996; Chaudhary 2017; Gürol ve Atsan 2006; Bozkurt ve Erdurur 2013; Korkmaz 2012) yer almıştır. 


\section{1. Ön Lisans Öğrencilerinde Girişimcilik Ĕ̆ilimi ile Demografik Faktörler İlişkisi}

Türkiye'de girişimcilik eğilimi araştırmalarının bulgularında hem ön lisans hem de lisans öğrenim düzeyindeki öğrencilerin girişimcilik eğilimlerinin (bir kısım araştırmalar istisna tutulursa: Bilge ve Bal 2012) genellikle "yüksek" düzeyde olduğu sonucuna (Bozkurt ve Erdurur 2013; Yavuz ve Yavuz 2017; Akçakanat, Mücevher ve Çarıkç1 2014; Aksoy ve Yalçınsoy 2017; Solmaz vd. 2014; Tays1 ve Canbaz 2014; Tekin,Özkul ve Demir 2014; Topal ve Şahin 2017) ulaşılmıştır. Alan yazındaki bu sonuçlara dayanarak, bu araştırmada da "Ön lisans ögrencilerinin girişimcilik eğilimleri ortalama skorlarl yüksek düzeydedir" hipotezi $\left(\mathrm{H}_{1}\right)$ kurulmuştur.

Türkiye'de yapılan araştırmalarda cinsiyet ile girişimcilik eğilimi ilişsisini açıklayan araştırma bulguları araştırmadan araştırmaya farklılık göstermektedir (Pazarcık 2016, 162). Hatta sayısı çok az da olsa, kimi araştırmalarda kadın öğrencilerin girişimcilik eğilimlerinin erkeklerden daha yüksek olduğu sonucuna da ulaşılmıştır (Sezer 2013, 76). Bir takım araştırmalarda kadın öğrencilerin girişimcilik eğilimini oluşturan boyutlardan yenilikçilik ve kararlılık boyutlarında erkek öğrencilerden daha yüksek düzeyde girişimcilik eğilimine sahip oldukları, diğer boyutlar bakımından ise farklılaşmadıkları sonucuna ulaşılmıştır (Solmaz vd. 2014, 49). Girişimcilik eğilimini, düşünce, proje ve yatırım boyutlarıyla ele alan bir takım araştırmalarda, yalnızca yeni projeler geliştirme boyutu bakımından kadın öğrencilerin erkeklerden daha yüksek ortalamaya sahip oldukları, diğer boyutlar bakımından farklılaşmanın olmadığı sonucuna ulaşılmıştır (Büyükyılmaz vd. 2015). Alan yazında cinsiyet ile üniversite öğrencilerinin girişimcilik eğilimi arasındaki ilişkiyi açıklayan (ister Türkiye örneklemlerinde ister Türkiye dışındaki örneklemler üzerinde yapılsın) araştırmaların bulgularında genellikle cinsiyetin girişimci eğilimle ilişkisi olmadığı yönünde sonuçlara ulaşılmaktadır (Farrington, Venter ve Louw 2012; Bilge ve Bal 2012; Talaş, Çelik ve Oral 2013; Akçakanat, Mücevher ve Çarıkçı 2014; Çatır, Şimşek ve Ölekli 2015; Mirza ve Dağdeviren 2016; Gençay ve Döven 2019; Yavuz ve Yavuz 2017, Yalçınsoy ve Aksoy 2018). Bununla birlikte erkek öğrencilerin daha yüksek girişimci eğilime sahip oldukları yönünde bulguları olan (yine ister Türkiye örneklemlerinde ister Türkiye dişındaki örneklemler üzerinde yapılsın) araştırmalar da alan yazında yer almaktadır (Şeşen ve Basım 2012; Dağıstan, Mısırlı ve Tanrısever 2019; Doğaner ve Altunoğlu 2010; Erçelik ve Mengeş 2019; Topal ve Şahin 2017). Bu araştırmada “Ön lisans öğrencilerinin girişimcilik ĕgilimleri ortalama puanları, cinsiyete göre farklılaşır” hipotezi $\left(\mathrm{H}_{2}\right)$ kurulmuştur.

Alan yazında yaş ile üniversite öğrencilerinin girişimcilik eğilimi arasındaki ilişkiyi açıklayan bir takım araştırmalarda, kimi üniversitelerde ön lisans ve lisans düzeyindeki öğrencilerde yaş arttıkça girişimcilik eğiliminin de arttığı ancak başka bir takım araştırmalarda ise azaldığı yönünde sonuçlar yer almaktadır (Pazarcık 2016).

Yaş farkının, üniversitede geçirilen süre (birinci sınıf / ikinci sınıf) ve alınan dersler (örneğin girişimcilik dersi ya da girişimcilik ile doğrudan ilgili dersler) bakımından kısmi bir farklılık oluşturabileceğinden, yaş farklılığının ön lisans öğrencilerinin girişimcilik eğilimi ile ilişkisinin gözlenebileceği ileri sürülebilir. Sınıf farklılığının değil de yalnızca yaş değişkeni ile girişimcilik eğilimi ilişkisini belirlemek üzere, bu araştırmada yalnızca ikinci sınıfta kayıtlı ön lisans öğrencilerinden veri toplanmıştır. Toplam dört dönemden oluşan eğitim programının, 3. döneminin sonunda öğrenim görmekte olan bir meslek yüksekokulu öğrencileri, araştırmanın örneklem kümesini oluşturmuştur. Yaş düzeyi ile girişimcilik eğilimi arasında ilişki olduğu sonucuna ulaşan araştırmalar şöyle sıralanabilir: Çatır, Şimşek ve Ölekli (2015), 20-22 yaş aralığında olan öğrencilerin, 17-19 yaş aralığında olanlardan ve 23 yaşın üzerinde olan ögrencilerden daha yüksek girişimcilik eğilimi ortalamasına sahip olduğu sonucuna, Erçelik ve Mengeş (2019) ise 18-25 yaş aralığında olan öğrencilerin daha büyük yaşlarda olan öğrencilere göre daha yüksek girişimcilik eğilimi gösterdiği sonucuna ulaşmıştır. Topal ve Şahin (2017) ise 20 yaşın altındaki öğrencilerin girişimcilik eğilimlerinin, 20 yaşın üstündeki öğrencilerin girişimcilik eğilimlerinden daha düşük olduğu sonucuna ulaşmıştır. Türkmen ve İşbilir (2014), 3. sınıfta öğrenim gören spor eğitimi bölümü öğrencilerinin, 1. ve 2. sınıfta öğrenim görenlerden daha yüksek girişimcilik eğilimine sahip olduklarını belirlemiştir. Yalçınsoy ve Aksoy (2018), lisans düzeyindeki 4. sınıfta öğrenim gören öğrencilerin, birinci ve ikinci sınıftaki öğrencilerin girişimcilik eğilimi ortalamasından daha yüksek ortalamaya sahip olduğu sonucuna ulaşmıştır. Solmaz vd. (2014), üniversite 1.,2.,3.,4. sınıf öğrencilerindeki girişimcilik eğilimi boyutlarından başarma arzusunun ve kararlılığın ortalama skorlarının, sınıflar arasında farklılaştığı ancak diğer dört boyut bakımından sınıflar arasında farklılaşmadığı sonucuna ulaşmıştır. Bir takım araştırmalarda, girişimcilik eğiliminin boyutlarından yenilikçilik ve kendine güven bakımından yaştaki artışın, girişimcilik eğiliminde de artış ile ilişkili olduğu sonucuna ulaşılmış, ancak diğer boyutlar bakımından yaş düzeyinin girişimcilik eğilimi ile ilişkili olmadığı sonucuna ulaşılmıştır (Korkmaz 2012). Bu araştırmada "Ön lisans ögrencilerinin girişimcilik eğilimi ortalama puanları, yaş gruplarına göre farklılaşır" hipotezi $\left(\mathrm{H}_{3}\right)$ kurulmuștur.

Büyükyılmaz, Karakaya ve Yıldıran (2015), Mirza ve Dağdeviren (2016), yaş ile girişimcilik eğilimi arasında ilişki olmadığı sonucuna ulaşmışlar, aynı doğrultuda Taysı ve Canbaz (2014), girişimcilik eğilimi ortalamalarının, 18-29 yaş aralığında oluşturulan altı ayrı grupta birbirinden farklılaşmadığı sonucuna varmışlardır. Chaudhary'nin (2017) aktardığına göre, Amerika, İspanya ve Çin'de 1000 üniversite öğrencisi üzerine yapılan araştırmalarda yaş düzeyinin girişimcilik eğilimi ile ilişkili olmadığı sonucuna ulaşılmıştır. Doğaner ve Altunoğlu (2010), üniversite 1. sınıf ve 4. sınıf öğrencilerini girişimcilik eğilimi bakımından karşılaştırdığı araştırmasında ortalamalar arasında farklılık olmadığı sonucuna ulaşmıştır. Gül ve Beyşenova (2018), 18-22 yaş aralığında olanlar ile 23-27 yaş aralığında olanlar arasında girişimcilik eğilimi ortalamaları bakımından fark olmadığı sonucuna ulaşmıştır.

Korkmaz (2012), ikinci öğretim türünde kayıtlı ön lisans öğrencilerinin, girişimcilik eğilimi boyutlarından yalnızca yenilikçilik ve risk alma ortalamalarının, birinci öğretimde kayıtlı olanlardan daha yüksek olduğunu, diğer boyutlar bakımından ilişkinin var olmadığı sonucuna ulaşmıştır. Alan yazında üniversitelerde normal ve ikinci öğretim türlerinde 
kayıtlı olmanın, öğrencilerin girişimcilik eğilimi ile ilişkisi olmadığını bulgulayan araştırmalar (Tekin, Özkul ve Demir 2014; Karakulle ve Karakaya 2017) yer almaktadır. Bu araştırmada “Ön lisans öğrencilerinin girişimcilik eğilimi ortalama puanlarının, normal öğretim ve ikinci öğretim türüne kayıtlı olma durumuna göre farklılaşır” hipotezi $\left(\mathrm{H}_{4}\right)$ kurulmuştur.

Türkiye'de gençlerin büyük bir kısmının, iş kurana / bulana kadar, evlenene kadar büyük ölçüde ailelerinin desteğini aldıkları bilinen bir gerçektir. Hatta bu desteğin dünyanın başka birçok ülkesinden farklı olarak iş bulma / kurma sonrasında da güçlü bir biçimde devam ettiği de söylenebilir. Türkiye sosyo-kültürel yapılanmasında aile kurumunun ve aile bağlarının bireylerin yaşamları üzerinde son derece güçlü etkileri olduğu söylenebilir (Eroğlu 2015, 136). Yalnızca çekirdek aile tipi bağlamında değil, geniș aileye de mensubiyet ve bağların güçlü olmasının, bireylerin / öğrencilerin kişilik özelliklerinin, girişimcilik eğilimi bakımından olumlu yönde etkileneceği yönündeki varsayım öne sürülebilir. Bireyin gelişiminde aile üyeliği ve aile bağları, pozitif sosyal çevre desteği (Aytaç ve İlhan 2007, 113) yanında genellikle ekonomik birtakım destekleri de içermektedir. Ekonomik yönden güçlü biçimde desteklenen öğrencilerin ise, ekonomik bakımdan daha az desteklenen bireylerden iktisadi faaliyetlere ve sosyal faaliyetlere yaklaşımları bakımından farklılık gösterecekleri söylenebilir. Beklenildiği üzere birtakım araştırmalarda, aile gelir düzeyinin girişimcilik eğilimi ile ilişkili olduğu, aile gelirinin yüksek olması halinde girişimcilik eğiliminin de yüksek olacağı yönündeki sonuçlara ulaşılmıştır (Arslan 2002; Şeşen ve Basım 2012; Kılıç, Keklik ve Çalış 2012; Uygun, Mete ve Güner 2012; Yurtkoru, Kuşcu ve Doğanay 2014; Aydın ve Öner 2016). Gürel, Altınay ve Danielle (2010), girişimcilik niyetinin (iş kurma niyetinin) / (yani girişimci özelliklere sahip olmak ya da girişimci eğilime sahip olmak değil), aile geliri düzeyi ile pozitif ilişkili olduğu sonucuna ulaşmışlar, ancak Çelik vd. (2014) bir ilişki olmadığı sonucuna ulaşmışlardır. Bununla birlikte alan yazındaki birtakım araştırmaların sonuçlarında, üniversite öğrencilerinin aile gelir düzeyleri ile öğrencinin girişimcilik eğilimi arasında bir ilişki bulunamamıştır (Akçakanat, Mücevher ve Çarıkçı 2014). Bunun nedeni aile gelirinin yüksek olduğu, kimi ailelerde yetişen kimi bireylerin küçük yaşlardan itibaren ailesinden yardım almaya alışması ve süreçte pasifleşmesi olabilir. Hayatta karşılaşılan zorluklarla mücadele etmek, problemlerin çözümü için çabalamak bireyin gelişim sürecinde girişimci eğilimini destekleyici bir rol üstlenebilir. Ancak aile gelirinin yüksek olması halinde, doğrudan (kestirme yoldan) bireyin girişimci eğiliminin kısıtlanacağı yönündeki bir iddia savunulamaz. Zira bireylerin üyesi oldukları ailede çocuk yetiştirme ve eğitim tarzı, yaşanılan bölgedeki sosyo-kültürel yapı, sosyo-ekonomik yapı gibi başkaca faktörler de dikkate alınmalıdır. Bu araştırmada "Ön lisans ögrencilerinin girişimcilik eğilimi ortalama skorlarl, aile gelir düzeyine göre farklılaşır” hipotezi $\left(\mathrm{H}_{5}\right)$ kurulmuştur.

\section{Yöntem}

$\mathrm{Bu}$ araştırma, kesitsel yapıda, nicel araştırma deseninde ve ilişkisel tarama modeli ile yürütülmüştür. Veri toplama amacıyla anket tekniği kullanılmıştır. İki bölümden oluşan anketin ilk bölümünde girişimcilik eğilimini test eden 23 madde, ikinci bölümünde ise katılımcıların demografik niteliklerini belirlemeye yönelik altı soru yer almıştır. Girişimcilik eğilimi ölçeği Yılmaz ve Sünbül (2009) tarafından geliştirilen “Üniversite Öğrencilerine Yönelik Girişimcilik Ölçeğil"nden alınmıştır.

Yılmaz ve Sünbül (2009) tarafından geliştirilen ölçek, faktör analizi ile 43 maddeden 36 maddeye indirgenmiştir. Aynı ölçekteki 40 maddeyi kullanarak girişimcilik ile ilgili algı ve tutumları tespit etmeyi amaçlayan Bilge ve Bal (2012)'ın araştırmasında 27 ifade, 6 faktör altında toplanmıştır. Konakay vd. (2017) tarafından üniversite öğrencilerinin girişimcilik eğilimlerini tespit etmek için de Yılmaz ve Sünbül (2009) tarafından geliştirilen ölçek kullanılmıştır. Bu araştırmada yapılan faktör analizi sonucunda 4 faktör ile 14 ifade elde edilmiştir. Araştırmamız, Bilge ve Bal (2012) tarafından elde edilen 27 maddelik ölçek ile yürütülmüştür. Ancak araştırmamız amacının nihai girişimcilik eğilimini ölçmeye yönelik olması nedeniyle araştırma analizleri 23 ifadenin ortalaması ile icra edilmiş, girişimcilik eğilimini oluşturan her bir faktör için ayrı bir analiz ve yorumlama yapılmamıştır. Girişimcilik eğilimini belirlemeye ait maddelerde Likert'in beşli cevap bileşeni kullanılmıştır (1: Hiç katılmıyorum, 2: Katılmıyorum, 3:Kısmen katılıyorum / kısmen katılmıyorum, 4: Katılıyorum, 5: Tamamen katılıyorum). Veri toplama amacıyla kullanılan anket ek.1'de görülmektedir.

Anketler, ön lisans öğrencilerine 2018-2019 eğitim öğretim yılının güz döneminde içinde ve girişimcilik dersi yapılırken anketin amacı aktarıldıktan sonra kâğıt ortamında dağıtılıp toplanması ile uygulanmıştır. Uygulama, Batı Anadolu bölgesindeki bir meslek yüksekokulunda tümü girişimcilik dersini alan 237 kişilik örneklem üzerinde yapılmıştır.

Araştırmanın problem cümleleri “Ön lisans öğrencilerinde girişimcilik eğilimleri hangi düzeylerdedir (çok zayıf, zayıf, orta, yüksek, çok yüksek)?” ve “Hangi demografik değişkenler (cinsiyet, yaş, öğrenim türü, ailenin gelir durumu), ön lisans öğrencilerinin girişimcilik eğilimleri üzerinde etkilidir?” olarak belirlenmiştir.

Araştırmada betimsel ve çıkarımsal yöntemler birlikte kullanılmıştır. Betimsel analizlerde frekans, yüzde, ortalama, standart sapma, mod, medyan gibi merkezi eğilim ölçütlerinden faydalanılır iken, çıkarımsal analizler için MannWhiyney U testi kullanılmıştır. 


\subsection{Güvenilirlik ve Normallik Testi}

Güvenirlik, ölçme aracının önemli teknik özelliklerinden biridir. Ölçme aracının ölçtüğü özellikleri, her zaman aynı şekilde ölçüp ölçemediğinin önemli bir göstergesidir (Williams ve Shellenberger 1996). Farklı bir ifadeyle, aynı anakitleden seçilecek başka örneklemlerde aynı yöntemle, aynı prosedür uygulanarak yapılacak farklı ölçümlerde benzer sonuçların elde edilme olasılığıdır. Güvenilirlik, sadece test edilen gruptan toplanan verilere ilişkin bir kavramdır (Şencan 2005). Güvenilirlik ölçümünde kullanılan çeşitli yöntemler bulunmaktadır. Bu yöntemlerden en sık kullanılanı Cronbach's Alpha katsayısıdır. Alpha iç tutarlılık güvenilirlik katsayısı, Likert tipi ağırlıklı puanlamanın yapıldığı araçlarla, maddelerin iç tutarlılığını tahmin etmede kullanılır (Okursoy ve Turan 2014). Cronbach's Alpha değerini düşüren dört madde araştırma analizlerinden çıkartılmış ve girişimcilik eğiliminin 23 ifade ile ölçümü yoluna gidilmiştir. Araştırmada Cronbach’s Alpha değeri 0,907 olarak bulunmuştur. Cronbach's Alpha katsayısı 0,80 ile 1 aralığında yer alan testler yüksek güvenilirliğe sahiptir (Alpar 2011; Nunnaly 1978). Cronbach's Alpha katsayısının verilen aralıkta olmasından dolayı anketlerden elde edilen verilere istatistiksel analizler uygulamanın mümkün olduğu sonucuna ulaşılmıştır.

Araştırmalarda kullanılacak olan istatistiksel tekniklerin belirlenmesinde temel ölçüt, analizlerde parametrik testlerin mi yoksa parametrik olmayan (non-parametrik) testlerin mi kullanılacağına karar verilmesidir. Parametrik testlerin kullanılabilmesi için bazı varsayımların sağlanıp sağlanmadığının test edilmesi gerekmektedir. Bu varsayımlardan biri de normal dağılım varsayımıdır. Normallik varsayımının ihlali, analizlerin istatistiksel gücünü ve sonuçlarının geçerliliğini düşürücü bir etkiye sahiptir (Wells ve Hintze, 2007). Parametrik testlerin uygulanabilmesi için "Veriler normal dă̆llmaktadır" şeklinde kurulan $\mathrm{H}_{0}$ hipotezinin kabul edilmesi gerekmektedir. Hipotezin kabul edilmemesi durumunda, verilere parametrik testler yerine parametrik olmayan testlerin uygulanması gerekmektedir. Normallik varsayımının testi için ilk aşamada çarpıklık (Skewness) ve basıklık (Kurtosis) değerlerinden faydalanılmıştır (Bkz. Tablo 2). Skewness (çarpıklık) ve Kurtosis (basıklık) katsayısının -1 ile +1 arasında olması durumunda veriler normal dağıldı ğına kanaat getirilebilir (Tabachnick ve Fidell, 2014). Ancak çarpıklık katsayısının bu sınırın bir miktar üzerinde olması nedeniyle diğer yöntemlerden de faydalanılması yoluna gidilmiştir. Örneklemin çok az sayıda $(n<20)$ olması ya da çok büyük hacimde olması halinde tercih edilmemekle birlikte, normallik dağılımının grafiksel yöntemlerden histogram ile testi de tercih edilen yöntemlerden biridir. Bu durumda çan eğrisi biçiminde bir görünüm, normal dağılıma karşılık gelmektedir (Demir vd., 2016: 133). Örneklemin histogram yoluyla elde edilen dağılım eğrisi Şekil 1'de görülmektedir.

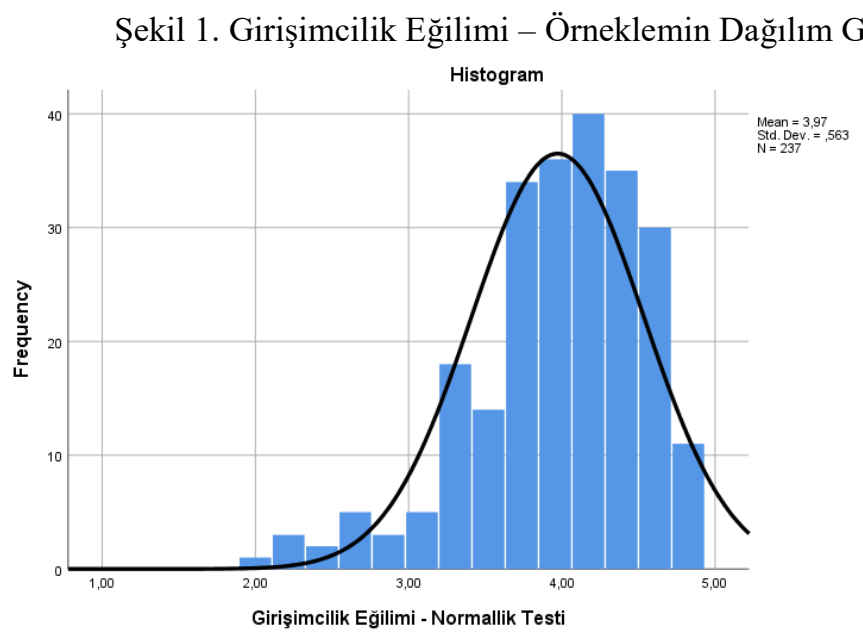

Şekil 1'de ki grafikte, dağılımın tam olarak çan eğrisi formunda elde edilememiş olması, nihai karar vermeye engel teşkil etmektedir. Bu nedenle çarpıklık ve basıklık katsayılarının kendi standart hatalarına bölünmesi ile elde edilen çarpıklık ve basıklık indeksleri değerlendirilmiştir. Bu indekslerin +2 ile -2 aralığında sıfıra yakın olması ve ayrıca standart sapma ile ortalamanın oranını yüzde olarak ifade eden bağıl değişim katsayısının 20-25 aralığında olması, normal dağılıma kanıt olarak gösterilmektedir (Tabachnick \& Fidell, 2014; McKillup, 2012). Hesaplanan değerlerin bu aralıklarda olmamasından dolayı (Bkz. Tablo 2) verilerin normal dağılmadığına kanaat getirilmiş ve parametrik olmayan testler ile analizler yapılmıştır. 


\section{Bulgular}

Katılımcıların demografik özelliklerine ilişkin bulgular Tablo 1'de görülmektedir.

Tablo 1. Katılımcıların Demografik Özellikleri

\begin{tabular}{|c|c|c|c|c|c|c|c|c|}
\hline $\begin{array}{l}\text { Medeni } \\
\text { Durum }\end{array}$ & $\mathrm{N}$ & Yüzde & Cinsiyet & $\mathrm{N}$ & Yüzde & $\begin{array}{l}\text { Ailenin Aylik } \\
\text { Geliri }\end{array}$ & $N$ & Yüzde \\
\hline Bekâr & 232 & $\% 97,9$ & Erkek & 115 & $\% 48,5$ & $<=4000 \mathrm{TL}$ & 208 & $\% 87,8$ \\
\hline Evli & 5 & $\% 2,1$ & Kadın & 122 & $\% 51,5$ & $>4000 \mathrm{TL}$ & 29 & $\% 12,2$ \\
\hline Toplam & 237 & $\% 100$ & Toplam & 237 & $\% 100$ & Toplam & 237 & $\% 100$ \\
\hline \multirow{2}{*}{ Yaş } & \multirow{2}{*}{$\mathrm{N}$} & \multirow{2}{*}{ Yüzde } & \multirow{2}{*}{$\begin{array}{l}\text { Öğrenim } \\
\text { Türü }\end{array}$} & \multirow{2}{*}{$\mathrm{N}$} & \multirow{2}{*}{ Yüzde } & Program & $N$ & Yüzde \\
\hline & & & & & & Lojistik & 9 & $\% 3,9$ \\
\hline \multirow{3}{*}{$<=22 \mathrm{Yaş}$} & \multirow{3}{*}{199} & \multirow{3}{*}{$\% 84$} & \multirow{2}{*}{ 1. Öğretim } & \multirow{2}{*}{146} & \multirow{2}{*}{$\% 61,6$} & İş Sağ. Güven. & 48 & $\% 21,1$ \\
\hline & & & & & & Bankacılık & 43 & $\% 18,9$ \\
\hline & & & \multirow{3}{*}{ 2. Öğretim } & \multirow{3}{*}{91} & \multirow{3}{*}{$\% 38,4$} & Menkul Kly. & 22 & $\% 9,6$ \\
\hline \multirow[t]{2}{*}{$>=23 \mathrm{Yaş}$} & \multirow[t]{2}{*}{38} & \multirow[t]{2}{*}{$\% 16$} & & & & $\begin{array}{l}\text { Halkla } \\
\text { Ilişikiler }\end{array}$ & 76 & $\% 33,3$ \\
\hline & & & & & & Büro Yönetimi & 30 & $\% 13,2$ \\
\hline Toplam & 237 & $\% 100$ & Toplam & 237 & $\% 100$ & Toplam & 228 & $\% 100$ \\
\hline
\end{tabular}

Tablo 1'e göre analiz birimindeki ön lisans öğrencilerinin \%97,1'i bekar, \%51,5'i kadın, \%84'ü 22 yaş ve altında, \%61,6’sı birinci öğretimde, \%33'ü halkla ilişkiler programı öğrencisi ve \%87,8'inin geliri 4.000 TL ve altı düzeydedir.

Tablo 2'de ön lisans öğrencilerinin girişimcilik eğilimlerine ilişkin olarak elde edilen betimsel istatistiki bulgular yer almaktadır.

Tablo 2. Girişimcilik Eğilimi Düzeyine İlişkin Merkezi Eğilim Ölçüsü Bulguları

\begin{tabular}{rlllll}
\hline \multirow{2}{*}{$\bar{x}$} & Mod & Medyan & $\begin{array}{l}\text { Standart } \\
\text { Sapma }\end{array}$ & Çarpıklık & Basıklık \\
\cline { 2 - 6 } & 4,26 & 4,0435 & 0,56301 & $-0,955$ & 1,11 \\
\hline \multirow{3}{*}{3,9727} & Çarpıklık & Basıklık & Çarpıklık & Basıklık & Bağıll \\
\cline { 2 - 6 } & Std. Hata & Std. Hata & İndeksi & İndeksi & Değişim \\
\cline { 2 - 6 } & 0,158 & 0,315 & 6,04 & 3,52 & $\% 14,17$ \\
\hline
\end{tabular}

Tablo 2'ye göre ön lisans öğrencilerinin girişimcilik eğilimi ortalaması, beşlik skalada 3,9727 düzeyindedir. Aralık ölçeğine göre bu ortalama, “yüksek" "düzeyi ifade etmektedir. Bu skora göre, ön lisans öğrencilerinin girişimcilik eğilimlerinin ortalamanın üzerinde olduğunu söylemek mümkündür. Bu bulguya göre, müfredat içeriklerindeki girişimcilik derslerinin, etkili bir biçimde ve teorik içeriğin yanında uygulamalarla da desteklenerek yürütülmesi, öğrencilerin bu eğilimlerinin mezuniyet sonrası iş fikirlerini “iş kurma” ş̧eklinde eyleme dönüştürmelerini olumlu yönde etkileyebilir.

Ön lisans öğrencilerinde cinsiyet ile girişimcilik eğilimi ilişkisine ait bulgular Tablo 3'de yer almaktadır.

Tablo 3. Ön Lisans Öğrencilerinin Cinsiyeti ile Girişimcilik Eğilimi İlişkisi

\begin{tabular}{rllllll}
\hline CINSIYET & $\begin{array}{l}\text { Mean } \\
\text { Rank }\end{array}$ & $\begin{array}{l}\text { Sum of } \\
\text { Ranks }\end{array}$ & $\begin{array}{l}\text { Mann- } \\
\text { Whitney } U\end{array}$ & $\begin{array}{l}\text { Wilcoxon } \\
W\end{array}$ & Z & p \\
\hline Erkek & 125,28 & 14407,5 & 6292,5 & 13795,5 & $-1,37$ & 0,171 \\
\hline Kadin & 113,08 & 13795,5 & & &
\end{tabular}

Ön lisans öğrencilerinde cinsiyet ile girişimcilik eğilimi ilişkisi, Mann-Whitney U testi ile analiz edilmiştir. Tablo 3'e göre ön lisans öğrencilerinin cinsiyeti, girişimcilik eğilimi üzerinde istatistiksel olarak anlamlı bir farklılık oluşturmamaktadır ( $\mathrm{p}=0,171>0,05)$.

Ön lisans öğrencilerinin yaşının girişimcilik eğilimi üzerine etkisine dair bulgular Tablo 4'de yer almaktadır. İstatistiksel analizde öğrencilerin yaşı 22 yaş ve altı ile 23 yaş ve üzeri olacak şekilde gruplandırılmıştır. 22 yaş ve altı grupta öğrencilerin yaşları 18-22 aralığında homojen dağılmakta iken 23 yaş ve üstünde bu dağılım daha az homojendir. 23 yaş ve üstü grupta 25 yaşın üstünde olan öğrenci sayısı 5'tir (Frekansl “1 ” olan yaşlar 26-28-30-32-37'dir.)

\footnotetext{
${ }^{2}$ Beşli Likert cevap bileşeni, dört puanlık bir genişliğe sahiptir. Bu genişlik beş eşit genişliğe ayrılarak 1,00-1,79 aras1 "çok düşük", 1,80-2,59 aras1 "düşük", 2,60-3,39 "aras1 orta", 3,40-4,19 aras1 yüksek, 4,20-5,00 aras1 çok yüksek olarak yorumlanmıştır (Yürekli ve Kalfa 2016).
} 
Akbaş, T., T., Arpat, B. / Journal of Yasar University, 2020, 15/57, 1-14

Tablo 4. Ön Lisans Öğrencilerinin Yaşı ile Girişimcilik Eğilimi İlişkisi

\begin{tabular}{rllllll}
\hline YAŞ & $\begin{array}{l}\text { Mean } \\
\text { Rank }\end{array}$ & $\begin{array}{l}\text { Sum of } \\
\text { Ranks }\end{array}$ & $\begin{array}{l}\text { Mann- } \\
\text { Whitney } \\
U\end{array}$ & $\begin{array}{l}\text { Wilcoxon } \\
\text { W }\end{array}$ & Z & $p$ \\
\hline$<=22$ Yaş & 112,15 & 12560,5 & 6232,5 & 12560,5 & $-0,081$ & 0,935 \\
\hline$>=23$ Yaş & 112,85 & 12639,5 & & & \\
\hline
\end{tabular}

Yaş ile girişimcilik eğilimi ilişkisi, Mann-Whitney U testi ile analiz edilmiştir. Tablo 4'e göre ön lisans öğrencilerinin yaşı, girişimcilik eğilimi üzerinde istatistiksel olarak $\% 95$ anlamlılık düzeyinde $(\alpha=0,05$ hata payında) anlamlı bulunmamıştır $(\mathrm{p}=0,935>0,05)$.

Ön lisans öğrencilerinin girişimcilik eğilimi ile öğrenim türü ilişkisi Tablo 5 'de yer almaktadır.

Tablo 5. Ön Lisans Öğrencilerinin Öğrenim Türü (birinci / ikinci öğretim) ile Girişimcilik Eğilimi İlişkisi

\begin{tabular}{|c|c|c|c|c|c|c|}
\hline $\begin{array}{r}O ̈ G R E N I M \\
T \ddot{U} R \ddot{U}\end{array}$ & $\begin{array}{l}\text { Mean } \\
\text { Rank }\end{array}$ & $\begin{array}{l}\text { Sum of } \\
\text { Ranks }\end{array}$ & $\begin{array}{l}\text { Mann- } \\
\text { Whitney } U\end{array}$ & $\begin{array}{l}\text { Wilcoxon } \\
W\end{array}$ & $Z$ & $p$ \\
\hline 1. Öğretim & 117,06 & 17091 & \multirow{2}{*}{6360} & \multirow{2}{*}{17091} & \multirow{2}{*}{$-0,552$} & \multirow{2}{*}{0,581} \\
\hline 2. Öğretim & 122,11 & 11112 & & & & \\
\hline
\end{tabular}

Ön lisans öğrencilerinde öğrenim türü ile girişimcilik ilişkisi de Mann-Whitney U testi ile analiz edilmiştir. Tablo 5'e göre, ön lisans öğrencisinin öğrenim türü ile girişimcilik eğilimi arasında istatistiksel olarak anlamlı bir ilişki bulunmamaktadır ( $\mathrm{p}=0,581>0,05)$.

Öğrencilerin ailelerinin geliri ile girişimcilik eğilimi ilişkisi Tablo 6'da yer almaktadır.

Tablo 6. Ön Lisans Öğrencilerinin Aile Gelir Düzeyi ile Girişimcilik Eğilimi İlişkisi

\begin{tabular}{|c|c|c|c|c|c|c|}
\hline $\begin{array}{r}\text { AILEE } \\
\text { GELIRII }\end{array}$ & $\begin{array}{l}\text { Mean } \\
\text { Rank }\end{array}$ & $\begin{array}{l}\text { Sum of } \\
\text { Ranks }\end{array}$ & $\begin{array}{l}\text { Mann- } \\
\text { Whitney } U\end{array}$ & Wilcoxon W & $Z$ & $p$ \\
\hline$<4000 T L$ & 113,75 & 23659 & \multirow{2}{*}{1923} & \multirow{2}{*}{23659} & \multirow{2}{*}{$-3,162$} & \multirow{2}{*}{0,002} \\
\hline$>=4000 \mathrm{TL}$ & 156,69 & 4544 & & & & \\
\hline
\end{tabular}

Ön lisans öğrencilerinin aile geliri ile girişimcilik eğilimi ilişkisi de Mann-Whitney U testi ile analiz edilmiştir. Tablo 6'ya göre, öğrencilerin aile geliri, girişimcilik eğilimi üzerinde, istatistiksel olarak anlamlı bir etki oluşturmaktadır $(p=0,002<0,05)$. Öğrencinin ailesinin geliri ile girişimcilik eğilimi arasındaki bu ilişki, geliri yüksek olan ailenin çocukları lehine olarak ortaya çıkmıştır. Buna göre, ailesinin geliri 4.000 TL ve üstü olan ön lisans öğrencilerinin girişimcilik eğilimleri, 4.000 TL'nin altında olan öğrencilere göre daha yüksektir.

\section{Tartışma ve Sonuç}

$\mathrm{Bu}$ araştırmada ön lisans öğrencilerinin girişimcilik eğilimleri ile cinsiyet, öğrenim türü (birinci / ikinci) demografik değişkenleri arasında ilişki olmadığı bulgulanmış, ancak aile ekonomik gelir düzeyinin ve yaş düzeylerinin ön lisans öğrencilerinin girişimcilik eğilimleri ile ilişkili olduğu ve ön lisans öğrencilerinde girişimcilik eğilimi ortalama skorlarının yüksek düzeyde olduğu bulgulanmıştır.

$\mathrm{Bu}$ araştırmanın sonuçları, ön lisans öğrencilerinin girişimcilik eğilimleri ortalama skorlarının yüksek düzeyde olduğunu göstermiştir ve araştırmanın $\mathrm{H}_{1}$ hipotezi kabul edilmiştir. Bu yönüyle alan yazında yer alan araştırmaların (Bozkurt ve Erdurur 2013; Yavuz ve Yavuz 2017; Akçakanat, Mücevher ve Çarıkçı 2014; Aksoy ve Yalçınsoy 2017; Solmaz vd. 2014; Taysı ve Canbaz 2014; Tekin, Özkul ve Demir 2014; Topal ve Şahin 2017) sonuçlarını desteklemiştir.

Alan yazında yer alan araştırmalardan birinde (Gümül, Çalık ve Kurt 2017) analiz edilen verilerin Türkiye’nin Doğu Anadolu Bölgesinde yer alan bir ilimizdeki meslek yüksekokulunun ön lisans öğrencilerinden sağlanması, ilgili araştırma sonuçlarında erkek öğrencilerin girişimci eğiliminin kadın öğrencilere göre daha yüksek düzeyde gözlemlenmesi ile kısmen ilişkilidir biçiminde bir yorum yapılabilir. Sosyo-kültürel yapının Türkiye'de homojen olmadığı, girişimcilik eğilimini ve girişimcilik niyetini açıklama bakımından bölgeler (Uygun, Mete ve Güner 2012; Taysı ve Canbaz, 2014) ve hatta iller arasında farklılaştığı söylenebilir. Türkiye'nin, girişimcilik eğilimini etkileyen kültürel özellikler bakımından büyük ölçüde farklı alt kültürlere sahip olduğu söylenebilir. İstanbul, İzmir ve Ankara ayrı tutularak, Türkiye'de Anadolu'nun bir takım illerinde girişimciliğin başarılı örnekleri çok sık gözlemlenebilirken, kimi illerinde bu örneklerin sayısının çok az olması kısmen sosyo-ekonomik ve sosyo-kültürel yapılardaki farklılaşmalarla ilişsili olabilir. Örneğin büyükşsehirde ve büyükşsehir yakınında olan bir yerleşim biriminde yaşıyor olmanın girişimcilik eğilimi ile ilişkili olduğu (Aydın ve Öner 2016; Türkoğlu, Tetik ve Açıkgöz 2017) söylenebilir. Girişimci eğilimin ortaya çıkabilmesi; toplumsal kültürün şekillendiği, sosyal yaşam içinde bireyin birey olarak var olabilmesini mümkün kılan sivil toplumla (Parlak ve Öztürk 2018; Gürel, Altınay ve Danielle 2010), birey-toplum dengesinin sağlıklı biçimde kurulmuş olmasıyla (Eroğlu 
2015, 188-189) ve bireylerin statü kazanma biçimleri bakımından açık toplum (Eroğlu 2015, 111) ile yakından ilişkilidir. Sosyal yaşamda bireyin birey olarak var olamadığı, birey-toplum dengesinin var olmadığı sosyo-kültürel yapılarda ise girişimci eğilimin (Ersoy 2010, 73-74) özellikle kadınlar arasında daha düşük düzeyde çıkması, en azından Türkiye'deki farklı bir takım bölgeler ve farklı bir takım örneklemler bakımından beklenen bir sonuçtur. Birey olma ve toplumda birey olarak var olabilme, Hofstede’in (2001) bireyci kültür karşısında kolektivist kültür boyutlarıyla ilgili kuramsal modeli bağlamından ayrı biçimde, ister kolektivist kültürde (örneğin Türkiye'de) olsun, ister bireyci kültürde (örneğin İngiltere) olsun, girişimcilik eğilimi ve girişimcilik niyeti ile ilişkili bir olgudur. Bu nedenle, bu araştırmadan elde edilen sonuçlarda cinsiyetin girişimcilik eğilimi ile ilişkili olmaması, araştırma örnekleminin Türkiye'nin Batı Anadolu bölgesindeki hem tarımsal hem de sanayi faaliyetlerinin son derece yoğun olduğu büyükşehire yakın bir ilçeden oluşturulmasından kaynaklanabilir. Sosyo-kültürel ve sosyo-ekonomik çevrenin ve sosyal coğrafyanın girişimcilik eğilimine (bireyin psikolojik özelliklerinin oluşmasına / bireyin kişiliğinin oluşmasına) yönelik etkileri gelecekte yapılacak araştırmaların konusu olabilir. Örneğin Türkiye'de, Malatya’nın Darende ilçesi girişimciliği, Denizli’nin Babadağ ilçesi girişimciliği (Tüzen ve Gültekin 2015, 187; Kavak 1999, 235), Kayseri’nin Hacılar ilçesi girişimciliğinin (Gençoğlu 2007, 377) analizlerinde, bireylerin girişimcilik eğilimleri üzerinde coğrafi, sosyal ve kültürel çevrenin etkileri gözlemlenebilir. Bu ilçelerin yerleşim alanlarının ya da coğrafi yapılarının tarım için uygun olmayan özellikte olması (Cengiz 2007, 133), burada yaşayan insanların geçmişten günümüze sanayi ve ticari alanlarda girişimci olmaya yönelmelerinde etkili olan faktörlerden biridir. Adı geçen ilçelerde, geçmişi tarihsel olarak günümüzden birkaç yüzyıl geriye dayanan ve halen devam ede gelen bu yönelim, sosyal ağların oluşmasını etkileyerek, beşeri sermayenin oluşmasını etkilediği gibi, girişimcilik eğilimini de besleyen / bireylerin meslek seçimlerini etkileyen bir yapıyı ortaya çıkarmış olabilir. Bu yapının oluşmasında sadece coğrafi yapının değil bunun yanında, inançların, geleneklerin, değerlerin (Erdem 2007, 359; Baktır 2007, 120; Sinanoğlu 2003, 2014) ve ayrıca Türkiye'de yüksek nüfuslu gelişen kent ekonomilerinin (büyükşehirlerin) varlığının / ortaya çıkmasının da etkili olduğu söylenebilir. Böyle bir sosyal örgütlenme yapısı ve çevresi (Tüzen ve Gültekin 2015, 187) içindeki ailelerde yetişen genç bireylerin, girişimci eğilimlerinin yüksek olması; kişiliğin oluşmasında bu yapının etkili olmasıyla (sosyal rol model kuramının da açıklamasıyla) ve ayrıca sosyal ve ekonomik yaşam içinde bireyin birey olarak var olabilmesine imkân sağlayan sivil toplum yapısının varlığı (Parlak ve Öztürk 2018) ile de ilişkili olabilir. Bu yapılarda girişimcilik eğiliminin kadın ve erkekler arasında istatistiksel olarak anlamlı düzeyde farklılaşmayacağı önerilebilir. Bu araştırmanın sonuçlarına göre de kadın ve erkek ön lisans öğrencilerinin girişimcilik eğilimi ortalama skorları birbirinden farklı düzeyde değildir ve araştırmanın $\mathrm{H}_{2}$ hipotezi kabul edilmemiştir.

Türkiye genelinde kadınların işgücü piyasasına katılımları oranı (15 yaş üstü, \%34,2) erkeklerden (15 yaş üstü, \%72,7) daha düşük düzeydedir (TÜİK, 2018). Türkiye'de, kadınların çalışma hayatına katılımlarının erkeklere göre düşük olmasıyla, yine genel olarak kadın girişimci sayısının erkeklere göre daha az olması ilişkili bir durumdur. Oysa bu araştırma bulgularında, kısmen değinilen kimi nedenlere bağlı olarak gözlendiği gibi, kadın ve erkek öğrencilerin girişimcilik eğilimleri ortalaması arasında istatistiksel olarak fark bulunmamaktadır. Genel olarak, Türkiye'nin tüm bölgelerinde kadınların girişimcilik eğilimlerinin desteklenmesi, girişimcilik niyetlerinin de oluşması ve girişimcilik niyetlerinin uygulamaya / gerçeğe dönüştürülmesi önündeki engellerin kaldırılmaya çalışılması, girişimci olmaya teşvik edilmeleri politika belirleyiciler için önerilebilir.

Yaş değişkeni, bu araştırmada ön lisans öğrencileri bakımından ağırlıklı olarak 18-22 aralığındaki öğrencileri (örneklemin \%84'ünü) içermekte, 23-37 yaş grubu ise örneklemin \%16'sını oluşturmaktadır. Bu araştırmada 23 yaş ve üstü grupta olup, 25 yaşın üstündeki öğrenci sayısı 5 idi. (Frekansı “1” olan yaşlar 26-28-30-32-37'dir.) 3-6 yaş aralığında olan bireylerde ay farkının bile davranış, algı ve tutumlarda önemli farklılık oluşturabilmesi, gelişim ve öğrenme psikologlarının kaydettikleri bir olgudur. Oysa araştırma örneklemi; ağırlıklı olarak 18-22 grubunda olanlardan ve az sayıdaki 23-37 yaş aralığındaki bireylerden oluşmaktadır. Genel olarak bu iki yaş grubundaki bireylerin bir ölçüde homojen oldukları söylenebilir. Nitelik bakımından bu homojenliğin asıl kaynağı örneklemi oluşturan bireylerin neredeyse tamamının, örgütsel kariyer safhalarının başlangıcında (halen keşif aşamasında) (Aytaç 1997, 62) olmalarıdır. İlave olarak hepsi de birbirine yakın puanlarla öğretim programına girmişler, büyük ölçüde aynı ya da yakın bölgelerden gelmişler, aralarındaki yaş farkı da genel olarak dört ya da beş yaştan ibaret olmuştur. Birbirinin ardılı olan ve gerçekte daraltılmış içeriğe sahip bu iki yaş grubu arasında, nitelikleri bakımından homojenlik bulunmasının da etkisiyle, ortalama girişimcilik eğilimleri skorları arasında farklılığın olmadığ araştırmalarda, ön lisans mezunu olan öğrencilerin girişimcilik eğilimleri ile ön lisans düzeyinde öğrencilik statüsünü sürdürmekte olanlar arasında girişimcilik eğilimleri karşılaştırılması yapılabilir. Böylece öğrencilik dönemindeki girişimcilik eğilimi, mezuniyet sonrası değişikliğe uğramış mıdır? sorusuna cevap aranarak eğer eğilimde bir evrilme var ise bunun nedenleri araştırılabilir.

Öğrenim türü (birinci / ikinci ögretim) bakımından, ön lisans öğrencilerinin girişimcilik eğilimi ortalamaları bu araştırmanın bulgularına göre farklılaşmamaktadır ve araştırmanın $\mathrm{H}_{4}$ hipotezi kabul edilmemiştir. Oysa ikinci öğretim öğrencilerinin gündüz saatlerinde çalışma hayatında yer almak gibi ya da sosyal çalışma faaliyetlerine katılmak gibi imkânlarının, normal öğretimde kayıtlı olan öğrencilerden daha yüksek olabileceğinden, girişimcilik eğilimleri ortalamalarının istatistiksel olarak anlamlı düzeyde daha yüksek olabileceği beklenebilirken, farklılaşmanın olmadığı sonucu ile karşılaşılmıştır. İkinci öğretime kayıtlı öğrenciler, normal öğretim öğrencilerine göre daha yüksek harç parası ödemek, belki okulun sosyal olanaklarından daha sınırlı düzeyde yararlanabilmek gibi dezavantaj oluşturabilecek faktörler nedeniyle, bu araştırmada birinci öğretime kayıtlı öğrencilerden daha yüksek girişimcilik eğilimine sahip olmadıkları bulunmuştur. Türkiye'de ön lisans ya da lisans düzeyinde öğrenim gören öğrencilerin, birinci öğrenim 
Akbaş, T., T., Arpat, B. / Journal of Yasar University, 2020, 15/57, 1-14

(gündüz) ya da ikinci öğrenim ( gece) ayrımı olmaksızın, büyük bir çoğunluğunun çalışma yaşamından uzak durdukları, genellikle yalnızca öğrenciliğin gerektirdiği bir takım sınırlı faaliyetleri yürütmekle yetindikleri söylenebilir. Bu savı destekleyen biçimde; gündüz ya da gece öğrenim türü bakımından, öğrencilerin girişimcilik eğilimi ortalamalarının farklılaşmamasının, paralel bir sonucu ortaya çıkardığı yorumu yapılabilir.

Bu araştırmada ön lisans öğrencilerinden aile ekonomik gelir düzeyi 4.000 TL. ve üzerinde olanların, 4.000 TL.'nın altında gelir düzeyine sahip olanlara göre daha yüksek girişimcilik eğilimine sahip oldukları bulgulanmış ve araştırmanın $\mathrm{H}_{5}$ hipotezi kabul edilmiştir. Örgütsel kariyer safhaları modeline göre keşif aşamasında olan bireylerin eğilimlerini belirleyen en önemli unsurlar çevrenin istekleri ile ailenin finansal kaynaklarıdır (Aytaç 1997, 63). Ailenin ekonomik gelirinin, ön lisans öğrencilerinin girişimcilik eğilimi ile ilişkisini açıklayan araştırmamızdaki bu bulguların, alan yazındaki araştırmaların (Arslan 2002; Şeşen ve Basım 2012; Kılıç, Keklik ve Çalış 2012; Uygun, Mete ve Güner 2012; Yurtkoru, Kuşcu ve Doğanay 2014; Aydın ve Öner 2016) sonuçlarını desteklediği görülmüştür. Buna göre, Türkiye Cumhuriyeti'nin makro ekonomik göstergelerindeki iyileşmeler/gelişmelerin, ön lisans öğrencilerinde girişimcilik eğilimini arttırıcı bir etki oluşturacağı söylenebilir. Bu bulguya bağlı olarak, öğrencilerin ekonomik refahlarını geliştirici nitelikteki yeni burs uygulamaları, mevcut bursların miktarlarının arttırılması ve 2019 yaz döneminden itibaren üniversite öğrencileri için uygulanmaya başlanacak ücretli sosyal çalışma programlarının, ön lisans öğrencilerinin girişimcilik eğilimlerine olumlu katkılar yapması beklenebilir. Ayrıca sosyal destek algısı yüksek olan ön lisans öğrencilerinde girişimcilik eğiliminin de yüksek olabileceği yönündeki önermelerin gelecekteki araştırmalarda test edilmesi önerilebilir. 


\section{KAYNAKÇA}

Acar, Osman Kürşat ve Ecehan Kazancı Yabanova. 2017. "Aktif İşgücü Piyasası Politikaları Çerçevesinde Kütahya İŞKUR'un Mesleki Eğitim Faaliyetlerinin İncelenmesi”. Mehmet Akif Ersoy Üniversitesi İktisadi ve İdari Bilimler Fakültesi Dergisi 4, no. 2: 85-111.

Ajzen, Icek. 2012. "The Theory of Planned Behavior" Lange, P. A. M., Kruglanski, E.T. \& Higgins, E.T. (eds.), Handbook of Theories of Social Psychology, Vol. 1: 438-459, London, UK: Sage.

Akçakanat, Tahsin, M. Hamdi Mücevher ve İ. Hüseyin Çarıkçı. 2014. "Sözel, Sayısal ve Eşit Ağırlık Bölümlerinde Okuyan Üniversite Öğrencilerinin Girişimcilik Eğilimlerinin Bazı Demografik Değişkenler Açısından İncelenmesi: SDÜ Örneği”. Afyon Kocatepe Üniversitesi İktisadi ve İdari Bilimler Fakültesi Dergisi 16, no. 2(Aralık): 137-153.

Aksoy, Beyhan, Mustafa Koçancı ve Mete K. Namal. 2019. “Girişimcilik Motivasyonu: Uygulamalı Girişimcilik Eğitimi Katılımc1ları Örneği”. Yönetim ve Ekonomi, no. 26(1): 109-129.

Aksoy, Cenk ve Ayhan Yalçınsoy. 2017. "Üniversite Öğrencilerinin Girişimcilik Eğilimleri Üzerine Bir Araştırma”, İsletme Araştırmaları Dergisi 9, no. 4: 341-359.

Aytaç, Serpil. 1997. Çalışma Yaşamında Kariyer. 1. Baskı, İstanbul: Epsilon Yayıncılık.

Alpar, Reha. 2011. Uygulamalı Çok Değişkenli İstatistiksel Yöntemler. 3. Edition. Ankara: Detay Yayıncılık.

Arslan, Kahraman. 2002. "Üniversiteli Gençlerde Mesleki Tercihler ve Girişimcilik Eğilimleri”. Doğuş Üniversitesi Dergisi 3, no. 2: 1-11.

Atalay, Muhammet, Harun Bayer ve Enes Çelik. 2018. "Meslek Yüksekokulunda Yapılan Eğitimin Mezunlarının İş Hayatındaki Etkisi Üzerine Bir Araştırma”. Kırklareli Üniversitesi Sosyal Bilimler Dergisi 2, no. 2(Aralık): 7188.

Aydın, Ensar ve Galip Öner. 2016. "Sosyal Bilgiler ve Sınıf Öğretmeni Adaylarının Girişimcilik Düzeylerinin İncelenmesi”. Ahi Evran Üniversitesi Kırşehir Eğitim Fakültesi Dergisi 17, no. 3(Aralık): 497-515.

Aytaç, Ömer ve Süleyman İlhan. 2007. “Girişimcilik ve Girişimci Kültür: Sosyolojik Bir Perspektif”. Selçuk Üniversitesi Sosyal Bilimler Enstitüsü Dergisi 18: 101-120.

Gençoğlu, Aylin Yonca. 2007. "Hacılar Ekonomisinin Sosyo-Kültürel Temelleri”, I. Hacılar Sempozyumu, 11-13 Mayıs, 377-384, Kayseri: Hacılar Belediyesi Kültür Yayınları.

Baktır, Mustafa. 2007. "Hacılar İnsanının Ticaret ve Sanayideki Başarısında Dini Değerlerin Önemi”, I. Hacılar Sетроzуити, (11-13 Mayıs 2007). 1:101-120, Kayseri: Hacılar Belediyesi Kültür Yayınları.

Bayraktar, Bülent ve Gülnara Karadeniz. 2017. "Kırgızistan-Türkiye Manas Üniversitesi Ön Lisans Öğrencilerinin Girişimcilik Eğilimlerinin Karşılaştırmalı Analizi”. Manas Sosyal Araştırmalar Dergisi 6, no. 4: 491-501.

Bilge, Hürriyet ve Vedat Bal. 2012. "Girişimcilik Eğilimi: Celal Bayar Üniversitesi Öğrencileri Üzerine Bir Araştırma”. Süleyman Demirel Üniversitesi Sosyal Bilimler Enstitüsü Dergisi 2, no. 16: 131-148.

Bozkurt, Öznur ve Erdurur, Kutbettin. 2013. "Girişimci Kişilik Özelliklerinin Girişimcilik Eğilimindeki Etkisi: Potansiyel Girişimciler Üzerinde Bir Araştırma” Girişimcilik ve Kalkınma Dergisi 8, no. 2(Kış): 57-78.

Büyükyılmaz, Ozan, Abdullah Karakaya ve Canan Yıldıran. 2015. "Girişimcilik Eğitimi Alan Bireylerin Demografik Özellikleri Açısından Girişimcilik Eğilimleri Arasındaki Farklar”. Girişimcilik ve Kalkınma Dergisi 10, no. 2: $105-125$.

Cengiz, Kurtuluş. 2007. "Hacılar'da Endüstrileşme ve Toplumsal Değişim: Weber’ci Bir Yaklaşımın Uygun(suz)lukları”, I. Hacılar Sempozyumu, (11-13 Mayıs 2007). 1:121-146, Kayseri: Hacılar Belediyesi Kültür Yayınları.

Chaudhary, Richa. 2017. "Demographic Factors, Personality and Entrepreneurial Inclination - A Study among Indian University Students". Education + Training 59, no. 2: 171-187.

Çatır, Ozan, Ali Şimşek ve Nilay Ölekli. 2015. "Meslek Yüksekokulu Öğrencilerinin Girişimcilik Eğilimlerinin Belirlenmesine Yönelik Ampirik Bir Çalışma”. (4. UMYOS Özel Sayısı), Electronic Journal of Vocational Colleges 5, no. 5(Aralık): 105-114.

Çelik, Adnan, Mehmet İnce ve Sezen Bozyiğit. 2014. "Üniversite Öğrencilerinin Girişimcilik Niyetlerini Etkileyen Ailesel Faktörleri Belirlemeye Yönelik Bir Çalışma”. Niğde Üniversitesi İktisadi ve İdari Bilimler Fakültesi 7, no. 3(Ekim): 113-124.

Dağıstan, Mustafa T., İrfan Mısırlı ve Canan Tanrısever. 2019. “Turizm Öğrencilerinin Girişimcilik Eğilimlerinin Demografik Özelliklere Göre Farklılıkları”. Manas Sosyal Araştırmalar Dergisi 8, no. 2: 2145-2162.

Demir, Ergül, Saatçioğlu, Özlem ve İmrol, Fatih. 2016. “Uluslararası Dergilerde Yayımlanan Eğitim Araştırmalarının Normallik Varsayımları Açısından İncelenmesi”. Curr Res Educ, no. 3: 130-148.

Doğan, Rana Ş. ve Veysel Yılmaz. 2017. "Üniversite Öğrencilerinin Girişimcilik Niyetlerinin Betimlenmesine Yönelik Bir Yapısal Eşitlik Modeli Önerisi”. Gazi Üniversitesi İktisadi ve İdari Bilimler Fakültesi Dergisi 19, no. 2: 655 675 .

Doğaner, Mustafa ve Ali E. Altunoğlu. 2010. “Adnan Menderes Üniversitesi Nazilli İktisadi ve İdari Bilimler Fakültesi İşletme Bölümü Öğrencilerinin Girişimcilik Eğilimleri”. Organizasyon ve Yönetim Bilimleri Dergisi 2, no. 2: 103 110. 
Erçelik, Mehmet A. ve Ersin Mengeş. 2019. “Girişimcilik Eğilimlerinin Bazı Demografik Özellikler Yönünden İncelenmesi: Meslek Yüksekokulu Öğrencileri Üzerinde Görgül Bir Araştırma”. Avrasya Sosyal ve Ekonomi Araştırmaları Dergisi 6, no. 5: 418-429.

Erdem, Ekrem. 2007. "Kayseri’de Sermaye Birikiminin Yapısı ve Değerler Sistemi: İslami Kalvinistler Çalışmasına Eleştirel Bir Yaklaşım”, I. Hacılar Sempozyumu, (11-13 Mayıs 2007). 1:359-375, Kayseri: Hacılar Belediyesi Kültür Yayınları.

Eroğlu, Feyzullah. 2015. Davranış Bilimleri, 14.Basım, İstanbul: Beta Yayınları.

Ersoy, Hüseyin. 2010. "Kültürel Çevrenin Girişimcilik Tercihine Etkisi”. Organizasyon ve Yönetim Bilimleri Dergisi 2 , no. 1: 71-77.

Farrington, Shelley M., Danie J.L. Venter ve Mattheus J. Louw. 2012. "Entrepreneurial Intentions: Demographic Perspectives of South African Business Students". South African Journal of Business Management 43, no. 3(September): 41-49.

Gençay, Emre ve Musa S. Döven. 2019. “Girişimci Kişilik Özelliklerinin Girişimcilik Niyetine Etkisi: Mersin Üniversitesi’nde Bir Araştırma”. Stratejik Yönetim Araştırmaları Dergisi 2, no. 1: 89-123.

Gençoğlu, Aylin Yonca. 2007. "Hacılar Ekonomisinin Sosyo-Kültürel Temelleri”, I. Hacılar Sempozyumu, 11-13 Mayıs, s.377-384, Kayseri: Hacılar Belediyesi Kültür Yayınları.

Gül, Hasan ve Aysuluu Beyşenova. 2018. "Kontrol Odağ1 ve Girişimcilik Eğilimi İlişkisi: KTMÜ Öğrencileri Üzerine Bir Araştırma”. Manas Sosyal Araştırmalar Dergisi 7, no. 2: 213-234.

Gümül, Fatih, Abdurrahman Çalık ve Halit Kurt. 2017. "Meslek Yüksekokulu Öğrencilerinin Girişimcilik Eğilimlerini İncelemeye Yönelik Bir Araştırma”. Afyon Kocatepe Üniversitesi Sosyal Bilimler Dergisi 19, no. 2(Aralık): 91107.

Gürel, Eda, Levent Altınay ve Roberto Danielle. 2010. "Tourism Students' Entrepreneurial Intentions". Annals of Tourism Research 37, no. 3: 646-669.

Gürol, Yonca ve Atsan, Nuray. 2006. "Entrepreneurial Characteristics amongst University Students: Some Insights for Entrepreneurship Education and Training in Turkey". Education + Training 48, no. 1: 25-38.

Hofstede, Geert. 2001. Culture's Consequences, Comparing Values, Behaviors, Institutions, and Organizations Across Nations, 2nd. Ed., California, USA: Sage Publications.

International Labor Office. 2018. "Kadın Girişimciler İçin Kılavuz”, Yayına hazırlayan: Aybaş, M.H., Uluslararası Çalışma Örgütü Yayınları, Ankara.

İrmiş, Ayşe, İbrahim Durak ve Lütfiye Özdemir. 2010. Girişimcilik Kültürü - Anadolu Girişimciliğinden Örnekler, Bursa: Ekin Yayınevi.

Karakulle, İsmail ve Abdullah Karakaya. 2017. "Üniversite Öğrencilerinin Girişimcilik Eğilimleri Üzerine Bir Araştırma". Akademik Sosyal Araştırmalar Dergisi 5, no. 46(Mayıs): 596-614.

Kavak, Şeref. 1999. "Çalışma Sermayesi Tüccardan Duran Varlıklar ve İşçilik Dokumacıdan Ortaklık Olmayan Ortaklık - Tekstilde Babadağ Modeli Kalkınma”, I. Babadağ Sempozyumu,(1-3 Aralık 1999). Denizli: Pamukkale Üniversitesi Yayınları.

Keat, Ooi Y., Christopher Selvarajah ve Denny Meyer. 2011. "Inclination towards Entrepreneurship among University Students: An Empirical Study of Malaysian University Students”. International Journal of Business and Social Sciences 2, no. 4(March): 206-220.

Kılıç, Recep, Belma Keklik ve Nevzat Çalış. 2012. “Üniversite Öğrencilerinin Girişimcilik Eğilimleri Üzerine Bir Araştırma: Bandırma İ̇BF İşletme Bölümü Örneği. Süleyman Demirel Üniversitesi İktisadi ve İdari Bilimler Fakültesi Dergisi 17, no. 2: 423-435.

Koh, Hian Chye. 1996. "Testing Hypotheses of Entrepreneurial Characteristics: A Study of Hong Kong MBA Students". Journal of Managerial Psychology 11, no. 3: 12-25.

Konakay, Gönül, Harun Demirkaya, S. Sevinç Altaş, Y. Arzu Morkoyunlu ve Ayfer Özmen.2017. "Y Kuşağının Girişimcilik Eğilimlerinin Demografik Değişkenler İle İncelenmesi” Uluslararası Turizm, Ekonomi ve Isşletme Bilimleri Dergisi 1, no. 1: 22-33.

Korkmaz, Oya. 2012. "Üniversite Öğrencilerinin Girişimcilik Eğilimlerini Belirlemeye Yönelik Bir Araştırma: Bülent Ecevit Üniversitesi Örneği”’. Afyon Kocatepe Üniversitesi İktisadi ve İdari Bilimler Fakültesi Dergisi 14, no. 2: 209-226.

Marques, Carla S., Joao J. Ferreira, Daniela N. Gomes ve Ricardo G. Rodrigues. 2012. "Entrepreneurship Education: How Psychological, Demographic and Behavioural Factors Predict the Entrepreneurial Intention". Education + Training 54, no. 8: 657-672.

McKillup, Steve. 2012. Statistics Explained: An Introductory Guide for Life Scientist. Second Edition, USA: Cambridge University Press.

Nunnaly, Jum C. 1978. Psychometric Theory, 2. Edition, New York: Mc Graw-Hill.

Okursoy, Algin ve Aykut H. Turan. 2014. An Empirical Examination to Define Factors Affecting Customers' Satisfaction Perceptions at a University Cafeteria. Doğuş Üniversitesi Dergisi 15, no. 1: 65-78.

Parlak, İsmet ve Öztürk, Enis. 2018. "Bireyler ve Birey Olamayan Bireyler: Liberalizm ve 19. Yüzyılın Çelişkileri", Mülkiye Dergisi, 42, no. 4: 565-592. 
Pazarcık, Yener. 2016. “Üniversitelerimiz Girişimci Yetiştirebiliyor mu? Üniversite Öğrencilerinin Girişimcilik Algısını / Eğilimini / Özelliklerini Ölçen Araştırmaların Sonuçsal Bir Değerlendirmesi”. (Girişimcilik özel sayısı)Sosyal ve Beşeri Bilimler Araştırmaları Dergisi 17, no. 37(Bahar): 140-169.

Sezer, Cemal. 2013.“Girişimcilik Kariyerine Yönelim Nedenleri ve Girişimcilik Dersinin Etkisi Üzerine Bir İçerik Analizi: KTMÜ Örneği”. Manas Sosyal Araştırmalar Dergisi 2, no. 8: 63-86.

Sinanoğlu, A. Faruk. 2003. “Darende'de Dini Hayat: Bazı Kurumsal Yapılara Değişimi ve Din İlişkisi”. Fırat Üniversitesi Ilahiyat Fakültesi Dergisi 8: 199-214.

Solmaz, Seyit Ahmet, Özlem Aksoy, Serkan Şengül ve Mehmet Sarışık. 2014. "Üniversite Öğrencilerinin Girişimci Kişilik Özelliklerinin Belirlenmesi: Turizm Lisans ve Ön Lisans Öğrencileri Üzerine Bir Alan Araştırması”. KMÜ Sosyal ve Ekonomik Araştırmalar Dergisi 16, no. 26: 41-55.

Şencan, Hüner. 2005. Sosyal ve Davranışsal Ölçümlerde Güvenilirlik ve Geçerlilik, 1. Basım, Ankara: Seçkin Yayıncılık. Şeşen, Harun ve H. Nejat Basım. 2012. "Demografik Faktörler ve Kişiliğin Girişimcilik Niyetine Etkisi: Spor Bilimleri Alanında Öğrenim Göre Üniversite Öğrencileri Üzerine Bir Araştırma”. (Özel sayı) Ege Akademik Bakış 12: 2128.

Şimşek, Osman. 2008. Zihniyet Açısından Türk Girişimciliğinin Sosyolojisi, 1. Basım, Ankara: Otorite Yayınları.

Tabachnick, Barbara ve Fidell, Linda. 2014. Using Multivariate Statistics. Sixth Edition, USA: Pearson.

Talaş, Emrah, Ali Kemal Çelik ve İbrahim Orkun Oral. 2013. "The Influence of Demographic Factors on Entrepreneurial Intention among Undergraduate Students as a Career Choice: The Case of a Turkish University".American International Journal of Contemporary Research 3, no. 12 (December): 22-31.

Taş, Ahmet. 2016.Girişimcilik Eğitimi ile Girişimcilik Eğilimi Arasındaki İlişkinin Parametrik Tekniklerle Analizi: Abant İzet Baysal Üniversitesi Örneği. Yüksek Lisans Tezi, Abant İzzet Baysal Üniversitesi, Sosyal Bilimler Enstitüsü, Bolu.

Taysı, Kemal ve Serdar Canbaz. 2014. “Ön Lisans Öğrencilerinin Girişimcilik Özelliklerini ve Eğilimlerini Belirlemeye Yönelik Bir Araştırma”. Electronic Journal of Vocational Colleges 4, no. 1: 59-67.

Tekin, Ömer A., Gökhan Özkul ve Yusuf Demir. 2014. "Turizm Öğrencilerinin Girişimcilik Düzeyleri Üzerine Bir İnceleme: Süleyman Demirel Üniversitesi Örneği”, 6th International Congress on Entrepreneurship (24-26 Nisan 2014), Bişkek, Kırgızistan.

Topal, Bayram ve Hasan Şahin. 2017. “Ön Lisans Öğrencilerinin Girişimcilik Eğilimleri Üzerine Bir Araştırma: Dumlupınar Üniversitesi Örneği”, 8. Uluslararası Girişimcilik Kongresi, (14-16 Temmuz). ed. Ş. Sakarya, M. Biniş, S. Kara ve İ. M. Bicil, 1: 957-975, Bandırma-Balıkesir.

Türkiye İstatistik Kurumu (TÜİK), (2018) https://biruni.tuik.gov.tr/medas/?kn=72\&locale=tr, (17.06.2019).

Türk Dil Kurumu (TDK) (2019) http://sozluk.gov.tr/, (16.06.2019).

Türkmen, Mustafa ve Uğur İşbilir. 2014. "Üniversite Öğrencilerinin Girişimcilik Eğilimlerinin Sosyo-Demografik Özellikler Açısından İncelenmesi”. Celal Bayar Üniversitesi Beden Eğitimi ve Spor Bilimleri Dergisi 9, no. 2: 1828.

Türkoğlu, Türkay, Semra Tetik ve Ayşen Açıkgöz. 2017. “Meslek Yüksekokulu Öğrencilerinin Sosyo-Demografik Özellikleri İle Girişimci Kişilik Özellikleri Arasındaki İlişkinin Araştırılması”. Journal of Yaşar University 12, no. 45: 1-13.

Tüzen, Hasan ve Mustafa Gültekin. 2015. Sosyal Sermaye - Denizli Tekstili Sanayisi - Babadă̆'lı ve Buldan'lı Aile Firmaları, 1.Basım, Denizli: Gökçe Yayınevi.

Ulucan, Serhat. 2015. Girişimcilik Eğiliminin ve Girişimcilik Ĕ̆ilimini Etkileyen Faktörlerin Analizi: Ortaöğrenimde Lise 3. ve 4. Sinıf Ögrencileri Üzerinde Bir Uygulama, Yüksek Lisans Tezi, Gazi Üniversitesi, Sosyal Bilimler Enstitüsü, Ankara.

Uygun, Mutlu, Sinan Mete ve Ebru Güner. 2012. "Genç Girişimci Adayların Girişimcilik Eğilimi ve Girişimcilik Özellikleri Arasındaki İlişkiler”. Organizasyon ve Yönetim Bilimleri Dergisi 4, no. 2: 145-156.

Vidic, Franc, Yeliz Yeşil, Özge A.S. Çalış ve Bülent Arpat. 2016. "Analyzing and Comparing the Properties of Woman Entrepreneurship in Slovenia and Turkey”. Asos Journal, no. 4(32): 352-371.

Wells, Craig ve Hintze, John. 2007. "Dealing with assumptions underlying statistical tests". Psychology in the Schools, 44(5), 495-502.

Williams, Marry Sue ve Sherry Shellenberger. 1996. How does your engine run? A leader's guide to the alert program for self-regulation. Albuquerque, NM: Therapy Works.

Yalçınsoy, Ayhan ve Cenk Aksoy. 2018. "Girişimcilik Eğilimlerinin Demografik Değişkenler Açısından İncelenmesi”. Business and Economics Research Journal 9, no. 4: 901-909.

Yavuz, Ayşe ve Halil İbrahim Yavuz. 2017. "Girişimcilik Eğilimlerinin Belirlenmesi: Taşkent MYO Öğrencileri Üzerine Bir Araştırma”. Mehmet Akif Ersoy Üniversitesi Sosyal Bilimler Enstitüsü Dergisi 9, no. 21(Ekim): 89-100.

Yıldız, Emel. 2010. "Meslek Yüksekokullarının Yerel Ekonomiye Katkıları: Babaeski Meslek Yüksekokulu Örneği”. Trakya Üniversitesi Sosyal Bilimler Dergisi 12, no. 2(Aralık): 87-102.

Y1lmaz, Ercan ve A. Murat Sünbül. 2009. “Üniversite Öğrencilerine Yönelik Girişimcilik Ölçeğinin Geliştirilmesi”. Selçuk Üniversitesi Sosyal Bilimler Enstitüsü Dergisi 21, 195-203.

Yurtkoru, E. Serra, Zeynep Kabadayı Kuşcu ve Ahmet Doğanay. 2014. "Exploring the Antecedents of Entrepreneurial Intention on Turkish University Students”. Procedia Social and Behavioral Sciences 150: 841-850. 
Akbaş, T., T., Arpat, B. / Journal of Yasar University, 2020, 15/57, 1-14

Yürekli, Emin ve Veli Rıza Kalfa. 2016. "Stajyer Öğrencilerin Mesleki Atılganlık Düzeylerinin Araştırılması; PAÜ Honaz Meslek Yüksekokulunda Bir Alan Araştırması”, ISVET 2016, (12-15Ekim 2016), 1: 684-691, Çorum: Hitit Üniversitesi Yayınları. 


\section{EK 1: Girişimcilik Eğilimi Anketi}

\section{Sayın Katılımcı,}

$\mathrm{Bu}$ araştırma. MYO öğrencilerinin girişimcilik eğilimlerini incelemek amacıyla yapılmaktadır. Lütfen hiçbir soruyu boş bırakmayınız. Adınızı-soyadınızı yazmayınız.

\section{Soruları yanıtlarken göstereceğiniz özen ve katkılarınız için teșekkür ederiz.}

\begin{tabular}{|l|l|l|l|l|}
\hline 1 & 2 & 3 & 4 & 5 \\
\hline $\begin{array}{l}\text { Kesinlikle } \\
\text { Katılmiyorum }\end{array}$ & Katılmiyorum & $\begin{array}{l}\text { Ne Kat1lyorum } \\
\text { Ne de Katılmıyorum }\end{array}$ & Katıliyorum & $\begin{array}{l}\text { Kesinlikle } \\
\text { Katıliyorum }\end{array}$ \\
\hline
\end{tabular}

Aşağıdaki ifadelerden her birine ne derece katıldığınızı, yukarıda verilen karşılıklara göre “ X" ile ilgili alana işaretleyiniz.

\begin{tabular}{|c|c|c|c|c|c|c|}
\hline No & ÖLÇÜM İFADESİ & 1 & 2 & 3 & 4 & 5 \\
\hline 1 & Kendimde farklı işler yapabilecek enerjiyi hissederim. & & & & & \\
\hline 2 & Risk almaktan çekinmem. & & & & & \\
\hline 3 & Yeni bir şeyleri denememe imkân veren projeler üzerinde çalışmayı severim. & & & & & \\
\hline 4 & $\begin{array}{l}\text { Eski fikirlere ve uygulamalara meydan okumayı ve daha iyilerini araştırmayı } \\
\text { severim. }\end{array}$ & & & & & \\
\hline 5 & Yeni bir perspektiften bakmama imkân sağlayan proje ve işlerle uğraşırım. & & & & & \\
\hline 6 & Geçmişte başkaları tarafindan kullanılmamış yeni yöntemlerle çalışmayı denerim. & & & & & \\
\hline 7 & Üzerinde çalıştığım bir konuda hata yapmaktan çekinmem. & & & & & \\
\hline 8 & Yeteneklerimi uygulayabilecek alanlar oluştururum. & & & & & \\
\hline 9 & Arkadaşlarımdan gelen bazı projelere katılmaktan çekinmem. & & & & & \\
\hline 10 & Başarıyı sağlayacak uygun yöntem ve tekniklerin arayışı içerisindeyimdir. & & & & & \\
\hline 11 & Karşıma çıkan firsatları değerlendirebilirim. & & & & & \\
\hline 12 & Elimdeki kaynakları bir araya getirerek verimliliğe dönüştürebilirim. & & & & & \\
\hline 13 & İşimde ve çalışmalarımda ortaya çıkan değişimlere açığımdır. & & & & & \\
\hline 14 & İşimde yaratıcılık yönüm güçlüdür. & & & & & \\
\hline 15 & Farklı işlere yönelik motivasyonlarım ve eğilimlerim güçlüdür. & & & & & \\
\hline 16 & $\begin{array}{l}\text { Ortak çalışmalarda işleri sıraya koymak benim için planlanmamış ancak doğal bir } \\
\text { görev niteliğindedir. }\end{array}$ & & & & & \\
\hline 17 & Kendi işimi kurabilirim. & & & & & \\
\hline 18 & Bir işte ya da uygulamada liderliği ele almaktan çekinmem. & & & & & \\
\hline 19 & $\begin{array}{l}\text { Eğer bir şeyi yapmayı aklıma koyarsam, hiçbir şeyin beni durdurmasına izin } \\
\text { vermem. }\end{array}$ & & & & & \\
\hline 20 & İş konusunda gelecekle ilgili etkili kararlar alabilirim. & & & & & \\
\hline 21 & Görevimin son derece zor olduğu zamanlarda elimden gelenin en iyisini yaparım. & & & & & \\
\hline 22 & Yaptığım planları yürütebileceğimden çoğunlukla eminimdir. & & & & & \\
\hline 23 & Hayatımı dış etkenlere bırakmam. & & & & & \\
\hline
\end{tabular}

